Notre Dame Law School

NDLScholarship

Journal Articles

Publications

1999

\title{
Retribution: Punishment's Formative Aim
}

John M. Finnis

Notre Dame Law School, john.m.finnis.1@nd.edu

Follow this and additional works at: https://scholarship.law.nd.edu/law_faculty_scholarship

Part of the Law Enforcement and Corrections Commons, and the Natural Law Commons

\section{Recommended Citation}

John M. Finnis, Retribution: Punishment's Formative Aim, 44 Am. J. Juris. 91 (1999).

Available at: https://scholarship.law.nd.edu/law_faculty_scholarship/871

This Article is brought to you for free and open access by the Publications at NDLScholarship. It has been accepted for inclusion in Journal Articles by an authorized administrator of NDLScholarship. For more information, please contact lawdr@nd.edu. 


\section{JOHN FINNIS}

The account of punishment offered by Friedrich Nietzsche in a central section of his On the Genealogy of Morals (1887) helps explain why this proudly malicious ${ }^{1}$ and profoundly confused thinker still is to be regarded as a participant in philosophy's conversation. There are, he says, two aspects of the problem of punishment to be distinguished:

on the one hand, that aspect of punishment which is relatively enduring -the custom, the act, the 'drama', a certain strict sequence of procedures -and, on the other hand, that aspect which is fluid - the meaning, the aim, the expectation which is attached to the execution of such procedures. ${ }^{2}$

Thus, things are not "as our naive genealogists of morality and law have previously assumed, thinking as they all do that the procedure was invented specifically for the purpose of punishment ..."3 Rather, it is to be assumed that "the procedure itself will be something older, earlier than its use as a means of punishment ...".4 Thus,

in a very late stage of cultural development (as, for example, in contemporary Europe) the concept 'punishment' in fact no longer possesses a single meaning, but a whole synthesis of 'meanings'. The whole history of punishment up to this point, the history of its exploitation to the most diverse ends, finally crystallises in a sort of unity which is difficult to unravel, difficult to analyse, and-a point which must be emphasised-completely beyond definition. (Nowadays it is impossible to say why people are punished: all concepts in which a whole process is summarised in signs escape definition; only that which is without history can be defined. $)^{5}$

Nietzsche here puts his finger on a genuine problem for social theory, the problem of defining social-historical concepts-or, more precisely, of giving any theoretical and general account of them beyond a listing of the various

1. "self-assured intellectual malice which belongs to great health" : 11.24, page 76 (Oxford: Oxford University Press, 1996), Douglas Smith, translator.

2. II.13 (Smith, p. 60).

3. Ibid.

4. Ibid.

5. Ibid. 
historically given terms ("signs"). (In the first two pages of Natural Law and Natural Rights, ${ }^{6}$ I give my own statement of the problem, and the rest of the chapter is my response--visibly to jurists such as Bentham, Kelsen, Hart, and Raz, invisibly to this passage from Nietzsche, on which I lectured in the early 1970s.) Nietzsche's discussion proceeds to offer a list, "far from exhaustive," of eleven "meanings" or "intentions" of punishment: a way of rendering harmless and preventing further damage; compensation for the victim; the isolation and containment of something which disturbs equilibrium; a means of instilling fear of those who determine and carry it out; "a form of forfeit [compensation] due in return for the advantages which the criminal previously [up to that point] enjoyed (as for example, when he is made useful as slavelabour in the mines)"; elimination of a degenerate element or branch; festivity, the violation and humiliation of an enemy; a means of producing a memory, whether for the person on whom the punishment is imposed (so-called rehabilitation) or for those who witness it; a form of remuneration in return for protection from excesses of revenge; a compromise with the spirit of revenge; a declaration of war against an enemy deemed dangerous and traitorous. ${ }^{7}$

This is a pretty good inventory. But Nietzsche is after bigger fish, the genealogy of morality itself, and in particular of conscience and one's "sense" or consciousness of guilt. Punishment itself, he says, does not normally induce a sense of guilt or bad conscience-indeed it typically, and historically, hinders or hindered the development of a sense of guilt, ${ }^{8}$ and in its origins it had nothing to do with desert or responsibility. Rather, it originated in notions of equivalence modelled on barter and sale. The criminal was debtor and the damaged creditor received compensation in the form of "the pleasure of being able to vent his power without a second thought on someone who is powerless ... the pleasure of violation [rape; doing violence]." ${ }^{\text {.9 }}$. But as the community grows stronger it ceases to regard crimes quite so seriously and begins to shield the offender from popular indignation and the fury of the person whom the offender has injured. ${ }^{10}$ And so we arrive at Nietzsche's "hypothesis" about the origins of conscience, in the first instance of "bad conscience" or guilt (II.16), but fundamentally of conscience itself (II.22). In this hypothesis we see the forerunner of the Freudian, ${ }^{11}$ the socio-biological, and countless other

6. (Oxford: Oxford University Press, 1980).

7. On the Genealogy of Morals, II.13 (p. 61).

8. Ibid., II. 14 (p. 62).

9. Ibid., II.5 (p. 46).

10. Ibid., II.10.

11. See Ernest Jones, The Life and Work of Sigmund Freud (Harmondsworth, Middlesex: Penguin, 1964), 596, summarizing Freud's thesis in Civilization and Its Discontents. 
reductive attempts to explain conscience as the sublimation or product of repression, death wishes, instincts, and so on.

I take conscience to be the deep sickness to which man was obliged to succumb under the pressure of that most fundamental of all changes- when he found himself definitively locked in the spell of society and peace. ... Every instinct which does not vent itself externally turns inwards - this is what I call the internalization of man: it is at this point that what is later called the 'soul' first develops in man. ... Those fearful bulwarks by means of which the state organization protected itself against the old instincts of freedom-punishment belongs above all to these bulwarks-caused all the instincts of the wild, free, nomadic man to turm backwards against man himself. Hostility, cruelty, pleasure in persecution, in assault, in change, in destruction, - all that turning against the man who possesses such instincts: such is the origin of 'bad conscience'. The man who is forced into an oppressively narrow and regular morality, who for want of external enemies and resistance impatiently tears, persecutes, gnaws, disturbs, mistreats himself, this animal which is to be 'tamed', which rubs himself raw against the bars of the cage, this deprived man consumed with homesickness for the desert, who had no choice but to transform himself into an adventure, a place of torture, an uncertain and dangerous wilderness-this fool, this yearning and desperate prisoner became the inventor of 'bad conscience'. ${ }^{12}$

In short: bad conscience, that is to say, one's conscience passing adverse judgment on one's own past conduct; is "the will to mistreat the self," 13 the "will to self-torture, that downtrodden cruelty of the internalized animal man who has been chased back into himself, of the man locked up in the 'state'"-locked up originally at the hands of "some horde or other of blond predatory animals [blond beasts], a race of conquerors and masters"14 (Nietzsche's admiration for whom is unconcealed)_-"in order to be tamed, the man who invented bad conscience in order to inflict pain on himself after the more natural outlet for this desire to inflict pain was obstructed ..."15 etc. Thus says Nietzsche at the end of this exposition of his "hypothesis," he has taken care "once and for all, of the origin of the "holy God," by which he means both conscience (which Kant had called our holy Lord) and God, another sublimation and projection of the tormented "sad, insane beast, man."16

12. On the Genealogy of Morals, II.16 (pp. 64-5).

13. Ibid., II.18 (p. 68).

14. Ibid., II.17 (p. 66).

15. Ibid., II. 22 (p. 72).

16. Ibid., II. 22 (p. 73). 
Within a few pages, Nietzsche has turned to the third and last part of his $O n$ the Genealogy of Morals. In it he drives his reflections and his rhetoric to their self-stultifying conclusion or impasse. The will to be truthful, to seek and hold to the truth, is itself a product of that sickness, conscience. The truth that conscience is a sickness and that God, the only ground of truth's value, is nonexistent therefore puts in question, renders problematic, the will to truth, the value of truth and of being truthful: "the value of truth must for once, by way of experiment, be called into question ..."." Nietzsche's phrase "by way of experiment" reveals the ultimately frivolous, dilettantish character of his thought, or the depth of the impasse to which his arbitrary assertions and denials have driven him. But he does not deny, indeed he here, at this juncture, admits that the "core"18 of conscience is, in fact, the will to truth, to truthfulness. ${ }^{19}$

It will be good to get away from the stale air of Nietzsche's writing-room. This part of the book-a book whose seductiveness you can see infecting a good deal in the academy today (quite evident, for example, in Judge Posner's Holmes Lectures at Harvard Law School in $1997^{20}$ ) —is headed by a quotation from an earlier work by Nietzsche:

Unconcerned [carefree], contemptuous [mocking], violent-this is how wisdom would have us be [or: thus wisdom wants us]: she is a woman, she only ever loves a warrior. ${ }^{21}$

Here the word "warrior" helps Nietzsche give gloss and luster to his admiration for rape (and to his truculence about self-contradiction, the truculence

17. Ibid., III.24 (p. 128). Also p. 126: "these hard, severe, abstemious, heroic spirits ... these pale atheists, anti-Christians, immoralists, nihilists ... these men in whom the intellectual conscience is alone embodied and dwells today... These men are far from free spirits: for they still believe in the truth!..." And here Nietzsche associates himself with the secretum of the highest grades of "that invincible order of the Assassins, that order of free spirits par excellence," the secretum that "nothing is true, everything is permitted." He calls this a "proposition" (true? false?) with "labyrinthine consequences" (ibid.), and it seems to be this that he has in mind when he says, III.27 (p. 135): "from now on morality will be destroyed through the coming to consciousness of the will to truth," viz. its becoming "conscious of itself as a problem"; and "this is the great drama in a hundred acts which is reserved for Europe over the next two thousand years, the most fearful, most questionable and perhaps also most hopeful of all dramas ...".

18. Ibid., III.27 (p. 134).

19. Ibid. (pp. 134-5).

20. Richard A. Posner, "The Problematics of Moral and Legal Theory," Harvard Law Review 111 (1998) 1637.

21. Nietzsche, "What is the Meaning of Ascetic Ideals?," in Smith, p. 77. 
which motivates the quotation). To get out of Nietzsche's study consider a real rape by real soldiers. A good account of such an act of violence by soldiers upon a woman, in November 1966 in central South Vietnam, was written up by Daniel Lang in 1969: Casualties of War, ${ }^{22}$ published elsewhere as "Incident on Hill 102." The account is told from the viewpoint of one of the five soldiers in a patrol whose leader, Sergeant Meserve, decided in advance to capture a young village woman, Phan Thi Mao, use her, with her hands tied, for sexual intercourse, and then kill her and conceal her body. All save one of the men participated in the rape or the murder or both. This man, Private Eriksson, realized then and there that "unless he took it upon himself to speak out, the fact of Mao's death would remain a secret." ${ }^{23}$ He did report the crime to his superiors back at base, who eventually and reluctantly did prosecute the other four for rape and murder. But the obstacles, the delays, and the warnings of the risks of revenge which Eriksson was running in pressing the charges were such that he could rely upon nothing other than interest in the truth being known and acknowledged, and thus upon the conscience of his superiors in the army and its justice system. At the trials, witnesses and defendants alike indicated their incredulity that useful fighting men should be being put on trial, though no one denied in principle that crimes such as rape and murder should be punished.

In Luke's Gospel, 23:39-41, we read:

One of the criminals who were hanging [on their crosses] kept deriding him and saying "Aren't you the Messiah? Save yourself and us!" But the other rebuked him, saying, "Don't you fear God, since you are under the same sentence of condemnation. And we indeed have been condemned justly, for we are getting our due for our actions, but this man has done nothing wrong."

Is Nietzsche right in holding that this acknowledgement of guilt and the accompanying recognition of punishment's justice are a mere sickness somehow transmitted from earlier generations of self-lacerating slaves and fools?

We should regard Nietzsche's genealogy of conscience and morality as factually, historically, far from grounded in evidence. But even if it were far better grounded in evidence than it is, we should also have to bear in mind, and adopt, Nietzsche's own recognition-acknowledged by him regardless of its subversion of his own project - that "there is a world of difference between the reason for something coming into existence in the first place and the

22. (New York: McGraw Hill Book Company, 1969).

23. Lang, Casualties of War, 54. 
ultimate use to which it is put, its actual application and integration into a system of goals." ${ }^{24}$ Our reactive inclinations, like our desires and aversions generally, can well be constitutionally ordered and directed by our understanding, by our capacity to understand and reason about opportunities and benefits, and the corresponding defaults and losses, common to us all. Our reactive instincts, even when they are interior to our intellectual capacities, our will, can be and, for truth's sake, should be integrated into this constitutional order in the soul, which is the source of all constitutional, decent order between persons, all society.

What is it, then, that with whatever admixture of emotion and confusion was nevertheless truly understood by the penitent malefactor and by Private Eriksson witnessing his fellow-soldiers' crimes on Hill 102?

The intrinsic worth of what truly benefits me has the same worth in the lives of any other persons who do or could share in that kind of benefit. This truth and our primary understanding of it are the primary source of all human community, more decisive than any emotion of sympathy or subrational instinct of solidarity. These emotions and instincts fittingly support and enliven one's intelligent grasp of the truth that every human good is a common good, but they also must contend with competing emotions or inclinations of self-indulgence and pride, dear to Nietzsche's heart. It is our practical knowledge, our understanding of intelligible opportunities and benefits precisely when we are thinking about what to choose and do, that can be and so, for the sake of truth and friendship, should be decisive. We have in mind the commanding status of this judgment in our deliberations, and in our reflections on our past choices and actions or omissions, when we speak of conscience: judgment about what is truly worthwhile and ought to be pursued, or done, or avoided.

Nietzsche claimed that generations of infliction of ferocious punishments were needed to create in human persons the memory required to take seriously one's own promise or to acknowledge one's "guilt" or responsibility. ${ }^{25}$ But what Nietzsche thus freely asserts, quite without evidence, should be freely denied. It is not lack of memory that stands or stood in the way of acknowledging the obligatoriness of one's promises or of one's duties of restitution or recompense. At most it was some kind of submerging of memories, a kind of overriding of stable willingness, of fidelity, of

24. On the Genealogy of Morals, 11.12 (p. 57).

25. Ibid., II.1-3. 
responsibility, and of regret, by countervailing desires to attend to one's own interests and pursue one's inclinations from now forward into the future, or perhaps by countervailing conventions encouraging indifference to the interests of persons outside a group. Part of the profound unity of our complex nature as individual human persons is one's capacity to recognize oneself as a being who lasts, from one end of this sentence to the other, from the beginning of deliberation through choice to execution of choice and enjoyment of the benefit one first envisaged (or regret at failing in one's purpose). And equally one can effortlessly recall and recognize as one's own one's parents, the undertakings others have made and on which one has relied or thought of relying, the harms one has done to others, the relationships one has formed, or maintained, or violated, the work one has done and now seeks payment for.

So Private Eriksson and the repentant malefactor (the "good thief") were, first and foremost, being truthful about the past and about how one person is related to another or others by virtue of what was done in time past. In stressing this, I do not concede that retribution is "purely backward-looking," as is so often said. The retributive shaping point of punishment, like other purposes to which punishment can be adapted, is forward-looking. The "medicinal" or "healing" point of punishment, of which Aquinas often speaks, is envisaged by him as including its purpose of retribution. There is a notable difference here between St. Thomas's terminology and the language of the Catechism of the Catholic Church. The catechism uses the term "medicinal" to refer exclusively to punishment's possible value as reformative: "Finally punishment has a medicinal value; as far as possible it should contribute to the correction of the offender." ${ }^{26}$ But when he speaks of punishment's medicinal function, Aquinas has in mind not only reform and deterrence and restraint and coercive inducement to decent conduct, but also the function which the Catechism calls primary: the redressing of the disorder caused by the offense. Why is this medicinal, curative healing? Because it is the healing of a disorder-precisely an unjust inequality-introduced into a whole community by the wrongdoer's criminal choice and action.

To understand this, it is necessary to set aside the assumption made all too casually by Nietzsche, but also by Bentham, Hart, and countless other theorists-the assumption that the essence of punishment is the infliction of pain. ${ }^{27}$ Putting punishment on the level of the sensory, sentient, and emotional

26. Catechism of the Catholic Church (rev. ed. 1997), paragraph 2266.

27. See H. L. A. Hart, Punishment and Responsibility: Essays in the Philosophy of Law (Oxford: Oxford University Press, 1968), 4: "I shall define the standard or central case of 'punishment' in terms of five elements: (i) it must involve pain or other consequences normally considered unpleasant ...". Here it is worth recalling that the French word for pain is douleur 
is an efficient way of blocking all understanding of its real point and operation, which is on the level of the will, that is to say of one's responsiveness to the intelligible goods one understands.

The essence of punishments, as Aquinas clearly and often explains, is that they subject offenders to something contrary to their wills - something contra voluntatem. ${ }^{28}$ This, not pain, is of the essence. Why? Because the essence of offenses is that in their wrongful acts offenders "yielded to their will more than they ought,"29 "followed their own will excessively,"30 "ascribed too much to their own preferences"31 - the measure of excess being the relevant law or moral norm for preserving and promoting the common good. ${ }^{32}$ Hence the proposition foundational for Aquinas' entire account of punishment: the order of just equality in relation to the offender is restored-offenders are brought back into that equality-precisely by the "subtraction" effected in a corresponding, proportionate ${ }^{33}$ suppression ${ }^{34}$ of the will which took for itself

not peine (the French word for punishment), just as the Latin for pain is dolor not poena (punishment).

28. II Scriptum super Libros Sententiarum Petri Lombardiensis (hereafter "Sent.") d. 42 q. 1 a. 2c; Summa Theologiae (hereafter "ST") I-II q. 46 a. 6 ad 2: "est de ratione poenae quod sit contraria voluntati"; likewise I q. 48 a. 5c; I-II q. 87 a. 2 c \& a. 6c; Summa contra Gentiles (hereafter "ScG") III c. 140 n. 5 [3149]. Still, punishment can be undergone and accepted voluntarily and freely \{libenter\}, on one's own account or on behalf of one's friend: IV Sent. d. 21 q. 1 a. 1 sol. 4c. See Finnis, Aquinas (Oxford: Oxford University Press, 1998), 212.

29. ST I-II q. 87 a. 6 c (plus voluntati suae indulsit quam debuit\}; III q. 86 a. $4 \mathrm{c}$ (same); $D e$ Rationibus Fidei ad Cantorem Antiochum (hereafter "Rat.") c. 7 [998] (same).

30. ST II-II q. 108 a. 4c (peccando nimis secutus est suam voluntatem).

31. Compendium Theologiae ad fratrem Reginaldum (hereafter "Comp.") I c. 121 (plus suae voluntati tribuens quam oportet\}. At the time of his Sent., Aquinas seems not to have understood the will's offense in terms of excess, and so did not squarely identify punishment as subtraction in the field of willing: see e.g. IV Sent. d. 15 q. 1 a. $4 c$; but II Sent. d. 42 q. 1 a. $2 c \&$ ad 5 gets very close to the clarity of the late works.

32. So the criminal's criminal offense is not, as such, against the victim so much as against "common justice," like the case discussed in ST II-II q. 66 a. 5 ad 3: I lend you something and, when its retum is overdue, I take it back by force or stealth instead of persuasion or due process of law; this conduct "does not harm (gravet) [you] but is an offense against common justice, inasmuch as [I am] usurping to [myself] the judgment on the matter and setting aside the due process of law [iuris ordine praetermisso\}."

33. II Sent d. 42 q. 1 a. 2 ad 5: "to the extent (tantum) that one has obeyed one's own will by transgressing the law ... , to that extent (quantum) one should compensate in the opposite direction (in contrarium\}, so that thus the equality of justice may be respected."

34. ST I-II q. 87 a. 1c: the essence of punishment, whether by one's own conscience in remorse, or by some external governing authority, is this suppression [depressio) by or on behalf of the order against which the wrongdoer was in insurrection. Note that, by contrast, the principal purpose of restitution (which is always to the victim) is "not that someone who has an excess (plus quam debet) should cease to have it, but that the person who has a deficiency \{minus\} should have it made good": II-II q. 62 a. 6 ad 1. 
too much (too much freedom or autonomy, we may say). ${ }^{35}$ In this way punishment "sets in order" the guilt ${ }^{36}$ whose essence was wrongful willing; and this (re)ordering \{ordinativa\} point of punishment can either be accounted remedial (medicinalis), ${ }^{37}$ or contrasted (for the Catechism of the Catholic Church is adopting one of Aquinas' ways of speaking) with the remedial (deterrent, reformative). ${ }^{38}$

Nietzsche saw the origins of punishment in the debtor-creditor relationship. Perhaps; the evidence is scant. But we should be concerned not with origins but with practical, moral intelligibilities. The debts from which just punishment liberates the offender ${ }^{39}$ are not debts to the victims who might be plaintiffs in a civil proceeding or might understandably but wrongly desire revenge. Rather, we may say, those debts are the advantage-the inequalitywhich, in the willing of an offense, is wrongly gained relative to all the offender's fellows in the community against whose law, and so whose common good, the offense offends ${ }^{40}$ : the advantage of freedom from external constraints in choosing and acting. ${ }^{41}$

Though the distinction between laws we call civil and laws we call criminal is no more clearly marked by Aquinas than by Aristotle or by Roman law, Aquinas does identify the basis for that distinction: the difference between one's duty to compensate and one's liability to punishment. Equally clearly

35. ST II-II q. 108 a. 4c: "the equality of justice is restored (reparatur) by punishment inasmuch as they undergo something contrary to their will"; Comp. I c. 121 [237]: "there is a restoring \{reductio\} to the order of justice by punishment, through which something is subtracted from the will"; ST I-II q. 87 a. 6c; likewise III q. 86 a. 4c: "through punishment's recompense (recompensationem) the equality of justice is restored \{reintegretur\}"; Rat. c. 7 [998]: "to restore them to the order of justice, something that they want needs to be taken away from \{ subtrahitur\} their will-which punishment does by taking away goods they want to have or imposing bads they are unwilling to undergo." See also Sententia Libri Ethicorum V.6 n. 6 [952], dealing simultaneously but to some extent distinctly with criminal punishment and civil compensation. Relevant goods which punishment takes away, and corresponding bads which it imposes, are life, bodily security, liberty, wealth, homeland, and honors [gloria]: ST II-II q. 108 a. $3 c$.

36. ScG III c. 146 n. 1 [3193].

37. As in e.g. II Sent. d. 36 q. 1 a. 3 ad 3.

38. As in e.g. ST II-II q. 108 a. 4 c.

39. Comp. I c. 226 [470].

40. So one merits reward or deserves punishment (which can only be rightly imposed by persons responsible for a community, administering its law) precisely as someone who is (or, like a visitor, is reasonably taken to be) a part of a community: ST I-II q. 21 a. 3 ad 2. a. $4 c$ \& ad 3; q. 92 a. 2 ad 3. There is, in the focal sense, no punishment (or reward) of subhuman animals: compare c. 143 [285].

41. So punishment cures and removes this inequality: IV Sent. d. 15 q. 1 a. 1 sol. $3 c$; ScG III c. 140 n. 5 [ 3149 ]; and footnote 35 above. 
he identifies the fundamental similarity of purpose: each of these branches of law concerns the restoration of an upset equality, the elimination of an unjustified inequality between persons; the restoration which justice requires can in either branch be called a recompense \{recompensatio\}. But the one branch looks to the losses incurred by specific persons, the other to a kind of advantage gained over all the other members of a community. For compensation \{reparatio; restitutio; satisfactio\} is essentially a matter of restoring to specific losers-to those who now have less than they ought ${ }^{42}$ - what they have been deprived of ${ }^{43}$ But punishment (poena; retributio $\left.{ }^{44}\right\}$ is essentially a matter of removing from wrongdoers a kind of advantage they gained, precisely in preferring their own will to the requirements authoritatively specified for that community's common good. ${ }^{45}$ So in litigation of the kind we call civil, the court has the duty to give plaintiffs their rights (ius suum\}, everything to which they are entitled as compensation for their injurious losses. ${ }^{46}$ But in proceedings of the kind we call criminal, the court can be authorized to impose, relax, remit, or withhold penalties with a view to wider considerations of public good \{publicae utilitati\}. ${ }^{47}$

42. IV Sent. d. 38 q. 2 a. 4 sol. 1 ad 1; ST II-II q. 67 a. 4 c.

43. ST II-II q. 62 a. 5c. Sometimes Aquinas distinguishes compensation (satisfactio\} for wrongful acts from retum (restitutio) of something which has been, or would otherwise be, wrongfully detained: IV Sent. d. 15 q. 1 a. 5 sol. 1 c. But often restitutio is a synonym for reparatio as the general category of civil compensation. The loss for which it would be unjust not to make restitution need not have resulted from the defendant's fault (iniustitia): ST II-II q. 62 a. $3 c$.

44. Caution: retributio, unlike the modern usage of the English word "retribution," extends (like "retribution" in older English) to reward of merit as well as punishment for guilt (see e.g. ST I-II q. 21 a. 3c); like many other key terms in Aquinas it takes its meaning-in-use from its context.

45. See e.g. ST I-II q. 87 a. $6 c$ \& ad 3.

46. ST II-II q. 67 a. 4 c: note that the plaintiff is here called accusator and the defendant a guilty person (reus) who is to be penalized (puniatur) by the award of damages; moreover, ibid. ad 3 states that victims of wrongdoing can be harmed by unwarranted remission of punishment, inasmuch as part of the compensation (recompensatio) to which they are entitled is a kind of restitution of a dignity interest [restitutio honoris \} through the punishment of the injurer(s). Note also: the civil court's order to pay compensatory damages or to return goods does no more than reaffirm a moral obligation which the defendant ought already to have discharged; but in respect of any (civil or criminal) penalties, defendants are morally entitled to await the court's order: II-II q. 62 a. 3c. But where there was an offense, the ruptured relationship between the parties (wrongdoer and victim) is not fully restored by restitution of what the victim lost; there must be some further making amends, some specific humilitas, by the wrongdoer: IV Sent. d. 15 q. 1 a. 5 sol. 1 ad 1.

47. IV Sent. d. 38 q. 2 a. 4 sol. 1 ad 1; ST II-II q. 67 a. 4 c. Being an aspect of the overall "care of the community," punishment can be imposed only by the authority of the supreme 
In short, retribution is one element in the general function of government: to uphold the proportionate equality of a just distribution of advantages and disadvantages, benefits and burdens, among the members of (and sojourners within) a political community. The precise benefit or advantage whose fair distribution it is the primary and shaping purpose of punishment to uphold is the advantage of freedom, in one's choosing and acting, from external constraints including the constraints appropriately imposed by laws made for the common good. Hart came close to identifying punishment's formative point and its place in the wider responsibility of the state's government and law to secure equality in justice. For he saw that morality-and he should have added, law-puts the strong and the cunning on a level with the weak and simple (something that disgusted Nietzsche).

Their cases are made morally alike. Hence the strong man who disregards morality and takes advantage of his strength to injure another is conceived as upsetting this equilibrium, or order of equality, established by morals; justice then requires that this moral status quo should as far as possible be restored by the wrongdoer. ${ }^{48}$

Here he is speaking of civil law, especially of tort, and its function and effect of compensating the victim of wrongdoing. He shows how the wrongdoer's advantage-taking applies even in cases of mere negligence:

One who has physically injured another either intentionally or through negligence is thought of as having taken something from his victim; and though he has not literally done this, the figure is not too far-fetched: for he has profited at his victim's expense, even if it is only by indulging his wish to injure or not sacrificing his ease to the duty of taking adequate precautions. $^{49}$

Reflecting, I believe, on this passage, Hart's student Herbert Morris was able to envisage punishment as retributive in aim by having the restoration of equality as its point: equality between the wrongdoer and the law-abiding. ${ }^{50}$ His argument was taken up by Jeffrie Murphy, ${ }^{51}$ and it remained only to identify the precise advantage gained by the offender relative to the lawabiding. When that advantage was identified as being what Aquinas had

ruler(s): ibid.; I-II q. 21 a. 4 c.

48. The Concept of Law, 2d ed. (Oxford: Oxford University Press, 1994), 165.

49. Ibid.

50. Herbert Morris, "Persons and Punishment," The Monist 52 (1968) 475-501.

51. Jeffrie Murphy, "Three Mistakes about Retributivism," Analysis 31 (1971) 109-112. 
pointed to-indulgence of will-the point of punishment, its general justifying aim, became once again clear. ${ }^{52}$ Hart never envisaged this line of thought clearly enough to reject it; it was blocked from his view by his assumption that punishment is by definition the infliction of pain-for how can adding pain to wrong restore anything or balance any account? ${ }^{53}$

What is done cannot be undone. But the purpose of retributive punishment is forward-looking, and not in vain. It is to secure that over the span of time which extends from before the crime until after the punishment, no one should have been disadvantaged-in respect of this particular but real kind of advantage-by choosing to remain within the law's confines. Punishment does not negate the crime, but it does negate, cancel out, the advantage the offender gained in the crime-the advantage not necessarily of loot or psychological satisfaction, but of having pursued one's own purposes even when the law required that one refrain from doing so. That there is point, value, merit, fittingness, in thus restoring equality between offenders and lawabiding, and cancelling the wrongdoer's unfair profit (advantage over them), is a truth which Eriksson and the good malefactor acknowledged. It stands undefeated by the assaults of Nietzsche and the neglect and misunderstanding of many.

Retributive punishment, the only genuine and justified form of punishment (whatever other purposes may rightly be pursued on the occasion and, in a sense, by means of it), is thus remote indeed from revenge. Punishment cannot be imposed by the victim as such. Indeed, it cannot rightly be imposed on behalf of the victim as such, but only on behalf of the community of citizens willing to abide by the law. Any practice of giving victims some role

52. Cf. John Finnis, "The Restoration of Retribution," Analysis 32 (1972) 132-5; Natural Law and Natural Rights, 261-6.

53. Hart, Punishment and Responsibility, 12 (also 18) tries to show that retributive principles of distribution, which he accepts (especially that only offenders should be punished, and only in proportion to their offense), "cannot be explained as merely a consequence of the principle [which he does not accept] that the General Justifying aim is Retribution ...". The argument is that if a law demanded immoral acts, so that disobedience to it was not immoral but morally required, punishment of persons who had not disobeyed it "would be a further special iniquity." But this is not convincing. Suppose that $Y$ disobeys the "hideously immoral" law and $X$ does not. $Y$ has as much moral right as $X$ to be immune from punishment, and $X$ cannot rightly complain that he, $X$, should have been given the opportunity of obeying the law before being punished. At most, $X$ could complain that there was no just reason for selecting him for punishment rather than $\mathbf{Z}$ or anyone else in the whole population. But this is no longer a complaint about violation of retributive principles of distribution; it is the same complaint as $X$ could make if he were selected for death in a program having nothing to do with offenses, e.g. a program of reducing population pressures by culling one person in ten. 
in criminal proceedings other than as witnesses, amongst other witnesses, to the fact of the offense must be highly questionable.

\section{III}

Nietzsche spoke of the doctrine of hell as the very climax of man's insane self-laceration, "a kind of madness of the will in psychic cruelty which simply knows no equal." 54 But he understood neither the doctrine nor the seriousness of wrongdoing -indeed, his envious admiration for lawless and immoral deeds of outrageous cruelty is scarcely concealed. He misconceived the notion of hell, in its sober essentials, because he conceived of punishment as infliction of pain, and failed to understand that hell is only by an extended analogy a matter of punishment. And the core of the analogy is not the choosing to inflict a penalty, a choosing (sentencing) which is central to human punishing. The analogy consists only in these two elements: subjection of the offender's will, and restoration of an equality between persons ${ }^{55}$ which was disturbed by the offender's wrongdoing. And even the subjection of will is essentially a matter of incompatibility between the offender's self-chosen stance (a stance now rendered unchangeable by that person's death) ${ }^{56}$ and the appropriate order within and between the creatures of the universe and their creator. The pains of loss are a bad side effect of this chosen stance, not the point of some selection of sentence.

In human punishments, on the other hand, penalties must be chosen by the judge from a range. There is no "natural" measure of punishment, that is to say, no rationally determinable and uniquely appropriate penalty to fit the crime. Punishment is the tradition's stock example of the need for determinatio, a process of choosing freely from a range of reasonable options none of which is simply rationally superior to the others. So there is no "natural," i.e. rational, requirement that murder, even the most atrocious, be punished capitally.

54. On the Genealogy of Morals, II.2 (p. 73).

55. Cf. John Paul II, Crossing the Threshold of Hope (London: Jonathan Cape, 1994), 186: "[T]here is something in man's moral conscience itself that rebels against any loss of this conviction [that there is eternal damnation]: Is not God who is Love also Justice? Can He tolerate these terrible crimes, can they go unpunished? Isn't final punishment in some way necessary to reestablish moral equilibrium in the complex history of humanity?"

56. Cf. Catechism of the Catholic Church, paragraph 1033: "To die in mortal sin without repenting and accepting God's merciful love means remaining separated from him forever by our own free choice. This state of definitive self-exclusion from communion with God and the blessed is called "hell'." 
